\title{
Effects of the invasive, nonindigenous seagrass Zostera japonica on nutrient fluxes between the water column and benthos in a NE Pacific estuary
}

\author{
Scott T. Larned ${ }^{1,2, *}$ \\ ${ }^{1}$ Coastal Ecology Branch, United States Environmental Protection Agency, 2111 SE Marine Science Drive, Newport, \\ Oregon 97365, USA \\ ${ }^{2}$ Present address: National Institute of Water and Atmospheric Research, PO Box 8602, Christchurch, New Zealand
}

\begin{abstract}
The effects of $Z$. japonica on dissolved nutrient fluxes between the water column and the benthos in Yaquina Bay, Oregon, USA were examined. Nutrient fluxes in Zostera japonica habitats were compared to those in adjacent unvegetated sediment in warm and cool seasons, and in daylight and darkness. In daylight, $Z$. japonica habitats were net sinks for nitrate $\left(\mathrm{NO}_{3}\right)$, ammonium $\left(\mathrm{NH}_{4}\right)$ and dissolved reactive phosphorus (DRP) in the warm season, and for $\mathrm{NO}_{3}$ and DRP in the cool season. At night in the warm season, $Z$. japonica habitats were net sinks for $\mathrm{NO}_{3}$ and $\mathrm{NH}_{4}$. Unvegetated sediments were net sources of $\mathrm{NH}_{4}$ to the water column in daylight in both seasons, and net sinks for $\mathrm{NO}_{3}$ at night in the warm season. On a diel basis, $Z$. japonica habitats habitats were net sinks for $\mathrm{NO}_{3}$ and $\mathrm{NH}_{4}$, and unvegetated sediments were net sources of $\mathrm{NH}_{4}$. Porewater $\mathrm{NO}_{3}$ and $\mathrm{NH}_{4}$ concentrations in unvegetated sediments were twice those in $Z$. japonica habitats. Nutrient fluxes in abutting monospecific patches of $Z$. japonica and the native seagrass $Z$. marina were also compared. Both species were sinks for $\mathrm{NO}_{3}, \mathrm{NH}_{4}$ and DRP. $\mathrm{NO}_{3}$ influx rates per unit above-ground biomass were higher in $Z$. japonica habitats, but areal rates of $\mathrm{NO}_{3}$ influx were higher in $Z$. marina habitats, reflecting the latter's higher biomass. The data demonstrate that $Z$. japonica invasions alter water columnbenthos nutrient fluxes. These alterations may in turn affect pelagic primary production. At current biomass levels, $Z$. japonica is estimated to remove 50 to 60 mole dissolved inorganic nitrogen (DIN) $\mathrm{h}^{-1}$ and 0.2 to 2.2 mole DRP $\mathrm{h}^{-1}$ from the Yaquina Bay water column, and continued expansion of $Z$. japonica in the estuary could lead to substantial reductions in nutrient availability.
\end{abstract}

KEY WORDS: Estuary - Invasion · Nonindigenous species · Nutrient flux · NE Pacific · Porewater · Seagrass $\cdot$ Sediment $\cdot$ Zostera japonica

Resale or republication not permitted without written consent of the publisher

\section{INTRODUCTION}

Invasions of estuaries by nonindigenous plants are increasing in frequency and geographic extent (Eno 1996, Cohen \& Carlton 1998, Ruiz et al. 1999). Aquatic plant invasions can alter nutrient cycling, primary production, and other ecosystem processes (Gordon 1998, Rooth \& Stevenson 2000). Once established, many nonindigenous aquatic plants have proven too costly to eradicate, which may preclude the restoration of normal ecosystem functions (Turner et al. 1998). Quantitative studies of the effects of nonindigenous estuarine species are rare; Ruiz et al. (1999) estimated that in the best-studied estuaries, the effects of fewer than $5 \%$ of the nonindigenous species have been measured. Some of these studies have linked changes in nutrient cycling in estuarine oligohaline zones to nonindigenous plants (e.g. Posey et al. 1993, Templer et al. 1998, Meyerson et al. 1999). In contrast, the effects of nonindigenous plants on nutrient cycling in lower (mesohaline and marine) estuary zones have not been reported. In light of the effects that nonindigenous plants have had in oligohaline zones, similar changes may be expected when mesohaline and marine zones are invaded. 
Seagrasses are major sinks and sources of dissolved nutrients in mesohaline and marine estuary zones (Pérez-Lloréns et al. 1993, Hemminga et al. 1994, Risgaard-Petersen et al. 1998, Hansen et al. 2000, Welsh et al. 2000). The dominant role of native seagrasses in nutrient cycling raises the possibility that the establishment of a nonindigenous seagrass would alter nutrient source-sink patterns in the invaded estuary. Such changes could affect sediment chemistry, and benthic and pelagic productivity.

The intertidal seagrass Zostera japonica Aeschers. \& Graebn. was introduced to NW North America from eastern Asia in the early to mid-20th century, possibly in shipments of Japanese oysters imported for mariculture (Harrison \& Bigley 1982). By the 1980s, Z. japonica was established in several estuaries between the southern Strait of Georgia and Coos Bay, Oregon (Harrison \& Bigley 1982, Posey 1988). By 1999, Z. japonica was present in most estuaries between Powell River, British Columbia and Coquille River, Oregon (author's pers. obs.).

In invaded estuaries of the NE Pacific, Zostera japonica forms dense patches in the intertidal zone, 0.3 to $2.4 \mathrm{~m}$ above mean lower low water (MLLW) (Harrison \& Bigley 1982, Posey 1988, Thom 1990). In the absence of $Z$. japonica, this zone is often unvegetated. Following colonization by seeds or asexual propagules, $Z$. japonica patches increase in size through rhizome growth and may expand at rates

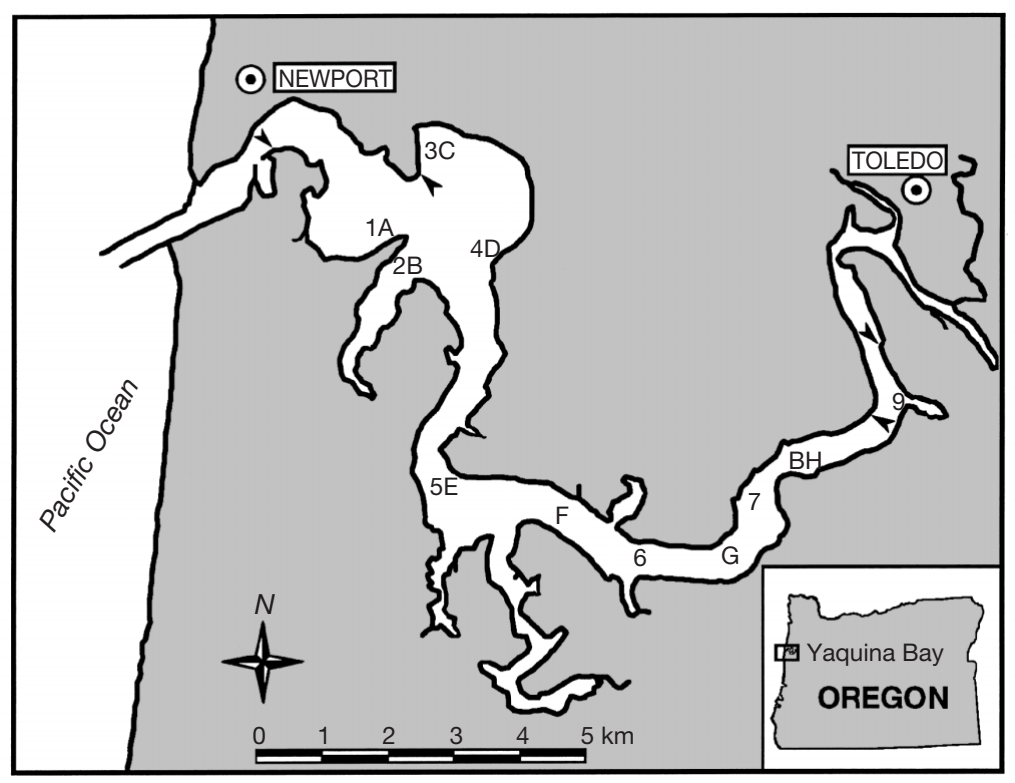

Fig. 1. Map of Yaquina Bay, central coast of Oregon. Numbers: locations of nutrient-flux experiments; letters: locations of permanent transects used to monitor Zostera japonica biomass. Arrowheads indicate upstream and downstream range limits of $Z$. japonica on north and south shores of Yaquina Bay in spring 2001
$>100 \% \mathrm{mo}^{-1}$ during the spring and summer growing season (Harrison \& Bigley 1982). Throughout its range in the NE Pacific, $Z$. japonica co-occurs with the native seagrass Zostera marina L. Z. marina occupies an elevation zone below that of $Z$. japonica, from $\sim 0.5 \mathrm{~m}$ above MLLW to subtidal depths, and there is generally an unvegetated band between the 2 seagrasses. At some sites, the lower extent of $Z$. japonica and the upper extent of $Z$. marina overlap, and the seagrasses form mixed patches and abutting monospecific patches (Thom 1990, Nomme \& Harrison 1991a).

In this study, I examined the effects of Zostera japonica on dissolved nutrient fluxes between the water column and the benthos in Yaquina Bay, Oregon. Areas of unvegetated sediment between $Z$. japonica patches served as reference sites for assessing the effects of the seagrass. At locations where abutting monospecific patches of Z. japonica and Z. marina occurred, I compared the effects of the nonindigenous and native seagrasses on nutrient fluxes. Z. japonica, Z. marina and unvegetated sediments were determined to be net sources or sinks for nitrate $\left(\mathrm{NO}_{3}\right)$, ammonium $\left(\mathrm{NH}_{4}\right)$ and dissolved reactive phosphate (DRP) based on patterns of influx or efflux. The terms influx and efflux refer to nutrient removal from the water column, and nutrient release to the water column, respectively. Nutrient fluxes represent the net effects of entire benthic assemblages, e.g. seagrasses, epiphytic and benthic algae, sediments and sediment fauna. For brevity, the benthic assemblages associated with unvegetated sediments and with $Z$. japonica and $Z$. marina are referred to hereafter as 'habitats'.

\section{MATERIALS AND METHODS}

Study sites. The study was carried out in Yaquina Bay $\left(44.6^{\circ} \mathrm{N}, 124.0^{\circ} \mathrm{W}\right)$, a drowned-river estuary on the central coast of Oregon. The combined area of marine and mesohaline zones in Yaquina Bay is $18 \mathrm{~km}^{2}$, of which $40 \%$ is subtidal channel and $60 \%$ is intertidal mudflat, sandflat, and seagrass habitat. At the time the study was conducted, Zostera japonica covered $<5 \%$ of the intertidal area. $Z$. japonica occurs between 0.5 and $2 \mathrm{~m}$ above MLLW in Yaquina Bay. The longitudinal distribution extends for $18 \mathrm{~km}$, from the mixing zone near the mouth of Yaquina Bay at Newport through the mesohaline zone near Toledo (Fig. 1). Individual $Z$. japonica patches range in area from $<1$ to $>500 \mathrm{~m}^{2}$. Unvegetated areas adjacent to $Z$. japonica patches are 
frequently inhabited by dense populations of the thalassinid shrimp Neotrypaea californiensis Dana and Upogebia pugettensis Dana.

Nutrient flux experiments. Three experiments were conducted. Expt 1 was a comparison of nutrient fluxes in Zostera japonica and unvegetated sediment habitats in the warm and cool seasons. Nutrient flux measurements were made at locations spanning the longitudinal range of $Z$. japonica in the estuary (Fig. 1). Warm and cool seasons were delineated using sediment temperature data. Temperature loggers (Onset Corporation, TidbiT loggers) were continuously deployed from July 1999 to June 2000 in Z. japonica patches at $5 \mathrm{~cm}$ sediment depth at 1 of the study locations, and average daily temperatures were computed from the logger data. Lowest daily temperatures ( 3 to $4^{\circ} \mathrm{C}$ ) were in January, highest daily temperatures $\left(19\right.$ to $\left.20^{\circ} \mathrm{C}\right)$ were in August, and the median daily temperature $\left(10.6^{\circ} \mathrm{C}\right)$, was in March and October. These data were used to divide the study period into a warm season (May to September 1999) and a cool season (January to April 2000). Nutrient flux measurements were made at 9 locations in the warm season and repeated at 5 locations in the cool season.

Expt 2 addressed the possibility that nutrient fluxes in Zostera japonica and unvegetated sediment habitats are light-dependent, and exhibit diel patterns. Paired day-night experimental runs were conducted at 4 locations from May to August 1999 to compare nutrient flux rates in daylight and in darkness. The locations used for this experiment were also used for Expt 1, but different $Z$. japonica and unvegetated sediment patches were used.

Expt 3 was a comparison of nutrient fluxes associated with the native and nonindigenous seagrasses. Nutrient flux measurements were made from April to June 2000 in abutting Zostera japonica and Z. marina patches at 3 locations. At each site, the seagrass patches were at the same tidal elevation. The locations used for this experiment were also used for Expt 1, but different $Z$. japonica patches were used.

Nutrient fluxes were measured using benthic chambers. Chambers were installed in 2 pieces to minimize sediment disturbance. The first piece, a $42 \mathrm{~cm}$ diameter $\times 10 \mathrm{~cm}$ long PVC coupler, was inserted in the sediment 4 to $5 \mathrm{~d}$ before the experiment, with the top edge flush with the sediment surface. The second piece, a $41 \mathrm{~cm}$ diameter $\times 40 \mathrm{~cm}$ long PVC pipe with a clear acrylic lid, was installed immediately before the experiment by holding it underwater to fill with seawater, then inserting it into the top edge of the coupler. The chambers enclosed $1140 \mathrm{~cm}^{2}$ of substratum and 461 of seawater. A large volume:area ratio $\left(0.4 \mathrm{~m}^{3} \mathrm{~m}^{-2}\right)$ was used to minimize the effect of changing nutrient concentrations on diffusive fluxes (Forja \& Gomez-
Parra 1998). The acrylic lids were equipped with battery-operated 70 rpm stirrers, and sampling and incurrent ports for withdrawing and replacing water. Stirrer propellers were trimmed to length to ensure that the water in chambers was mixed from top to bottom without sediment suspension.

During each run of Expts 1 and 2, 2 benthic chambers were installed over Zostera japonica and 2 over unvegetated sediment. During each run of Expt 3, 2 chambers were installed over $Z$. japonica and 2 over Z. marina. Chambers were installed parallel to the shoreline, $2 \mathrm{~m}$ apart, without regard for the density of underlying seagrass. In all runs, a fifth chamber was used as a control for nutrient fluxes in the water column. The control chamber had a closed bottom, otherwise it was identical to the open-bottomed chambers. After the open-bottomed chambers were installed, the control chamber was filled with water from the study site, and placed in a 1001 water bath. The water in the bath was continuously replaced with estuary water to maintain the chamber at ambient temperatures. Experimental runs were 4 to $7 \mathrm{~h}$ long, and spanned the high slack tide. In Expt 2, nighttime measurements were made first, the PCV couplers were left in place at the end of the run, and the chambers were replaced in the couplers on the following day for the daylight measurements.

Water samples were collected from the chambers by attaching a syringe to the sampling port, opening the incurrent port, withdrawing and discarding $60 \mathrm{ml}$ of water to rinse the port and syringe, then withdrawing and retaining $60 \mathrm{ml}$ of water. Less than $2 \%$ of the chamber volume was replaced during an experimental run. Water samples were collected at 30 to $120 \mathrm{~min}$ intervals, and were filtered immediately through GF/F filters into HCl-washed Nalgene bottles, placed on ice, then frozen in the laboratory until analysis. Nutrient concentrations were determined using a Lachat Instruments QwikChem 8000 analyzer at Analytical Laboratory, University of California Santa Barbara. Nutrient flux rates $\left(\mu \mathrm{mol} \mathrm{m} \mathrm{m}^{-2} \mathrm{~h}^{-1}\right)$ were calculated from linear regressions of nutrient concentration on elapsed time during the first 3 to $5 \mathrm{~h}$ of the experiment runs. Rates of change in nutrient concentrations in the control chamber were used to correct water column-benthos flux rates from the same experimental run. Nitrite $\left(\mathrm{NO}_{2}\right)$ concentrations in ambient water samples were always $<5 \%$ of $\mathrm{NO}_{3}$ concentrations, and $\mathrm{NO}_{2}$ fluxes are not reported here. Irradiance (photosynthetically active radiation) was measured next to the chambers, $10 \mathrm{~cm}$ above the substrate, during daylight runs using a Li-Cor LI 192SA sensor and a LI 250 meter. The acrylic chamber lids reduced irradiance in the chambers by 10 to $15 \%$.

Sediment, seagrass and porewater samples. Core samples of sediments and Zostera japonica or Z. marina 
tissues enclosed by the benthic chambers were collected during the low tide following each run of Expts 1 and 3. Three sizes of cores were collected during Expt 1: large ( $8 \mathrm{~cm}$ diameter $\times 15 \mathrm{~cm}$ deep) cores for seagrass biomass measurement, medium $(3.5 \mathrm{~cm}$ diameter $\times$ $15 \mathrm{~cm}$ deep) cores for particulate nutrient and grain size analysis, and small $(3.1 \mathrm{~cm}$ diameter $\times 2 \mathrm{~cm}$ deep) cores for sediment chlorophyll a analysis. Sediment chlorophyll cores were not collected during Expt 3. Three replicate cores of each size were collected from the area beneath each chamber, and the data from replicate cores were averaged and treated as single samples in subsequent analyses.

In the laboratory, seagrass biomass cores were rinsed of sediment over a $0.5 \mathrm{~mm}$ mesh sieve, then above-ground (shoots, leaves, inflorescences) and below-ground (roots and rhizomes) portions were separated, dried to constant weight at $70^{\circ} \mathrm{C}$, ashed at $500^{\circ} \mathrm{C}$ for $4 \mathrm{~h}$ and reweighed for ash-free dry weight (AFDW) determination. The medium cores were homogenized, then divided into 3 portions: $150 \mathrm{~g}$ wet weight for sediment grain size analysis, $20 \mathrm{~g}$ for particulate organic carbon (POC) and particulate nitrogen (PN) analyses, and the remainder for particulate phosphorus (PP) analysis. Sediment grain size analysis followed Buchanan (1984). Combined sieve and pipette analyses were used to determine dry weights of 7 grain size classes $(4.0,2.0,1.0,0.5,0.25,0.125$ and $0.063 \mathrm{~mm}$, silt and clay). Mean grain sizes and sorting coefficients (arithmetic standard deviations) were calculated from grain size frequency distributions. POC and PN concentrations were measured with a Perkin Elmer 2400 elemental analyzer, PP concentrations were measured with an Alpken rapid flow analyzer. The small cores for chlorophyll a analysis were transferred to centrifuge tubes. Cold $90 \%$ acetone was added to each tube, the sediment-acetone mixture was sonicated, and chlorophyll was extracted for $48 \mathrm{~h}$ in darkness at $0^{\circ} \mathrm{C}$. The tubes were then centrifuged and chlorophyll a concentrations in the supernatants were measured with a Turner Design AU-10 fluorometer.

Porewater samples were taken from the sediment $20 \mathrm{~cm}$ from the benthic chambers. Porewater samplers were made from $10 \mathrm{~cm}$ lengths of $2.5 \mathrm{~cm}$ diameter PVC tube with caps on both ends. Two $10 \mathrm{~cm}$ Tygon tubes were inserted in holes in one of the caps. Slots were cut into the PVC tubes at $0.5 \mathrm{~cm}$ intervals, and the tubes were wrapped in Nitex screen (200 $\mu \mathrm{m}$ mesh) to allow solute exchange. Two or 3 samplers were installed near each benthic chamber base 4 to $5 \mathrm{~d}$ before the experimental run. The samplers were inserted vertically in $20 \mathrm{~cm}$ deep holes with the Tygon tubes protruding, and then filled with deionized water. Porewater samples were collected at low tide 7 to $10 \mathrm{~d}$ after the experimental run by withdrawing water with a syringe through one of the Tygon tubes. The second tube allowed air to displace sample water and prevented contamination with surrounding water. Porewater samples were processed for nutrient analysis as described above for benthic chamber samples. No porewater samples were collected during Expt 2.

Biomass monitoring. Permanent transects were established at 8 locations with large Zostera japonica patches (long axis $>40 \mathrm{~m}$ length) to monitor temporal changes in $Z$. japonica biomass. These locations spanned the longitudinal range of $Z$. japonica in Yaquina Bay (Fig. 1). At each location, a $40 \mathrm{~m}$ long transect was established parallel to the water line, bisecting the $Z$. japonica bed. Core samples $(8 \mathrm{~cm}$ diameter $\times 15 \mathrm{~cm}$ deep) were collected at 12 random points on each transect at 2 mo intervals for 22 mo (February 1999 to December 2000). The above- and below-ground biomass of $Z$. japonica in the cores was determined as described above.

Data analyses. Nutrient flux rates in Zostera japonica and unvegetated sediment habitats in the warm and cool seasons (Expt 1), and in daylight and darkness (Expt 2) were compared by factorial ANOVA. For Expt 3, nutrient fluxes in Z. japonica and Z. marina habitats were compared by 1 -way ANOVA. The normality of flux rate data was assessed using linear correlations of the flux rates for each treatment, with normal scores calculated from the same data. Correlation coefficients were $\geq 0.9$ in each case. Locations of experimental runs were used as blocks in ANOVAs. Time constraints prevented experimental runs from being conducted simultaneously at each location during each experiment, so runs were conducted at a different location every 6 to $18 \mathrm{~d}$ during each season. This approach risked confounding effects of locations with short-term temporal variability, i.e. dates within seasons. However, among-location differences in nutrient fluxes were generally larger than between-season differences (see 'Results'), and it was assumed that among-location differences were also greater than among-date differences.

The data from Expt 2 were used to estimate diel nutrient flux rates. The following assumptions were made: (1) water column-benthos nutrient flux only occurred when the study sites were immersed, not when they were emersed; (2) study sites were immersed at tidal heights $\geq 1.25 \mathrm{~m}$ above MLLW. This height corresponds to the center of the tidal range of Zostera japonica; (3) daylight periods were from local sunrise to local sunset, and dark periods were from sunset to sunrise. Average hours of immersion in daylight and darkness per day were taken from tidal predictions for Yaquina Bay at Newport, Oregon, using the WWW Tide and Current Predictor (available at http://tbone.biol.sc.edu/tide/sites_uswest.html). Diel 
fluxes were estimated as mean daytime flux rates multiplied by the immersed daylight period plus mean nighttime flux rates multiplied by the immersed dark period.

Seagrass and unvegetated sediment habitats were determined to be net sinks or net sources of each nutrient based on $95 \%$ confidence intervals (CI) around the mean flux rates. If a mean $\pm \mathrm{CI}$ flux rate was $>0$, the habitat was considered a net source; if a mean \pm CI flux rate was $<0$, the habitat was considered a net sink.

To quantify relationships between nutrient fluxes and seagrass biomass, flux rates were regressed on the seagrass biomass enclosed by the benthic chambers. Separate linear regressions were calculated for Zostera japonica in the warm and cool seasons (Expt 1) and for $Z$. japonica and Z. marina in the warm season (Expt 3). Associations between nutrient fluxes in the $Z$. japonica habitat and a suite of chemical and physical variables (ambient nutrient concentrations, sediment properties, temperature and irradiance) were examined by correlation analysis. Variable values used in correlations were means from the experimental runs.

Chemical and physical properties of sediments in adjacent Zostera japonica patches and unvegetated sediments in both seasons were compared by factorial ANOVA (Expt 1). Sediment properties in adjacent $Z$. japonica and $Z$. marina patches were compared by 1-way ANOVA (Expt 3).

\section{RESULTS}

\section{Ambient conditions and control chambers}

Experimental runs were conducted over a temperature range of 6 to $22^{\circ} \mathrm{C}$, and a salinity range of 16 to
$33 \%$. Water temperatures during the warm season runs of Expt 1 were always higher than in the cool season runs (Table 1). During some runs, a lens of brackish water was present when the chambers were filled on the rising tide, and salinity in the benthic chambers was then lower than the average salinity outside the chambers. Mean irradiance during daytime runs ranged from $126 \mu \mathrm{E} \mathrm{m} \mathrm{m}^{-2} \mathrm{~s}^{-1}$ in the cool season to 429-510 $\mu \mathrm{E} \mathrm{m} \mathrm{m}^{-2} \mathrm{~s}^{-1}$ in the warm season (Table 1). $\mathrm{NO}_{3}$ was the dominant form of inorganic nitrogen in the water column; ambient $\mathrm{NO}_{3}$ concentrations were 3 to $17 \times$ higher than $\mathrm{NH}_{4}$ concentrations and 40 to $180 \times$ higher than $\mathrm{NO}_{2}$ concentrations (Table 1). Elevated $\mathrm{NO}_{3}$ and $\mathrm{SiO}$ concentrations during the cool season portion of Expt 1 reflect dissolved nutrient loading to Yaquina Bay from the Yaquina River during high winter flows (Table 1).

Nutrient fluxes in the water column were measured during each experiment run using the control chamber. Rates of $\mathrm{NO}_{3}, \mathrm{NH}_{4}$, and DRP flux in the control chamber were always less than $10 \%$ of the rates in chambers installed over seagrass and unvegetated sediment habitats. For each nutrient in each experiment, $95 \%$ confidence intervals for mean flux rates in the controls included zero, indicating that the water column was not a significant sink for or source of inorganic nutrients.

\section{Expt 1. Nutrient fluxes in Zostera japonica and unvegetated sediment habitats}

Zostera japonica habitats were net sinks for $\mathrm{NO}_{3}$, $\mathrm{NH}_{4}$, and DRP during the warm season, and net sinks for $\mathrm{NO}_{3}$ and DRP during the cool season (Fig. 2a). $\mathrm{NH}_{4}$ fluxes in $Z$. japonica habitats in the cool season were

Table 1. Water temperature, irradiance, salinity and ambient nutrient concentrations during benthic chamber experiments. Values are means $\pm 1 \mathrm{SD}$; sample sizes in parentheses. nm: no measurement. DRP: dissolved reactive phosphorus

\begin{tabular}{|c|c|c|c|c|c|c|c|c|}
\hline \multirow[t]{2}{*}{ Experiment } & \multirow{2}{*}{$\begin{array}{c}\text { Temperature } \\
\left({ }^{\circ} \mathrm{C}\right)\end{array}$} & \multirow{2}{*}{ 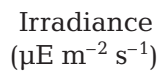 } & \multirow{2}{*}{$\begin{array}{l}\text { Salinity } \\
\text { (\%o) }\end{array}$} & \multicolumn{5}{|c|}{ - Ambient concentration $(\mu \mathrm{M})$} \\
\hline & & & & $\mathrm{NO}_{3}$ & $\mathrm{NH}_{4}$ & DRP & $\mathrm{NO}_{2}$ & $\mathrm{SiO}$ \\
\hline \multicolumn{9}{|c|}{ Expt 1} \\
\hline Warm season & $\begin{array}{c}15.7 \pm 2.2 \\
(40)\end{array}$ & $\begin{array}{c}429 \pm 565 \\
(36)\end{array}$ & $\begin{array}{c}26.1 \pm 5.7 \\
(40)\end{array}$ & $\begin{array}{c}7.9 \pm 5.3 \\
(9)\end{array}$ & $\begin{array}{l}2.9 \pm 1.0 \\
(9)\end{array}$ & $\begin{array}{c}1.0 \pm 0.5 \\
(9)\end{array}$ & $\begin{array}{c}0.2 \pm 0.1 \\
(9)\end{array}$ & $\begin{array}{c}58.7 \pm 17.5 \\
\text { (9) }\end{array}$ \\
\hline Cool season & $\begin{array}{c}8.6 \pm 1.4 \\
(26)\end{array}$ & $\begin{array}{c}126 \pm 209 \\
(15)\end{array}$ & $\begin{array}{c}21.9 \pm 6.5 \\
(26)\end{array}$ & $\begin{array}{c}35.4 \pm 20.2 \\
(5)\end{array}$ & $\begin{array}{c}2.3 \pm 0.5 \\
(5)\end{array}$ & $\begin{array}{c}0.7 \pm 0.2 \\
(5)\end{array}$ & $\begin{array}{c}0.2 \pm 0.0 \\
(5)\end{array}$ & $\begin{array}{c}86.9 \pm 20.6 \\
\text { (5) }\end{array}$ \\
\hline \multicolumn{9}{|l|}{ Expt 2} \\
\hline Daytime & $\begin{array}{c}16.0 \pm 4.3 \\
\quad(16)\end{array}$ & $\begin{array}{c}510 \pm 427 \\
(16)\end{array}$ & $\begin{array}{c}26.6 \pm 7.3 \\
(16)\end{array}$ & $\begin{array}{c}8.1 \pm 8.0 \\
(4)\end{array}$ & $\begin{array}{c}2.5 \pm 0.8 \\
(4)\end{array}$ & $\begin{array}{c}0.8 \pm 0.5 \\
(4)\end{array}$ & $\begin{array}{c}0.1 \pm 0.1 \\
(4)\end{array}$ & $\begin{array}{c}54.1 \pm 19.2 \\
(4)\end{array}$ \\
\hline Nighttime & $\begin{array}{c}15.5 \pm 2.6 \\
\quad(18)\end{array}$ & $\mathrm{nm}$ & $\begin{array}{c}25.8 \pm 4.9 \\
\quad(18)\end{array}$ & $\begin{array}{c}9.1 \pm 3.6 \\
(4)\end{array}$ & $\begin{array}{c}2.2 \pm 0.1 \\
(4)\end{array}$ & $\begin{array}{c}1.13 \pm 0.26 \\
(4)\end{array}$ & $\begin{array}{c}0.3 \pm 0.0 \\
(4)\end{array}$ & $\begin{array}{c}48.4 \pm 15.4 \\
(4)\end{array}$ \\
\hline Expt 3 & $\begin{array}{l}14.1 \pm 2.2 \\
\quad(16)\end{array}$ & $\begin{array}{c}383 \pm 240 \\
(12)\end{array}$ & $\begin{array}{c}25 \pm 7.0 \\
(16)\end{array}$ & $\begin{array}{c}13.7 \pm 3.8 \\
(3)\end{array}$ & $2.8 \pm 1.1$ & $\begin{array}{c}0.63 \pm 0.20 \\
(3)\end{array}$ & $\begin{array}{c}0.2 \pm 0.1 \\
\text { (3) }\end{array}$ & $\begin{array}{c}58.2 \pm 4.3 \\
(3)\end{array}$ \\
\hline
\end{tabular}


too variable to determine the net direction, i.e. the $95 \%$ CI for the mean flux rate included zero. Rates of $\mathrm{NO}_{3}$ flux in $Z$. japonica habitats were on average $5 \times$ greater than $\mathrm{NH}_{4}$ flux rates. Unvegetated sediments were sources of $\mathrm{NH}_{4}$ to the water column in both seasons (Fig. 2a). $\mathrm{NO}_{3}$ and DRP fluxes associated with unvegetated sediments were too variable to determine net directions.

$\mathrm{NO}_{3}$ and $\mathrm{NH}_{4}$ flux rates in Zostera japonica habitats were significantly higher than in unvegetated sediments (Table 2). Between-habitat differences in DRP fluxes were not significant. In the warm season, $\mathrm{NH}_{4}$ and DRP flux (a)
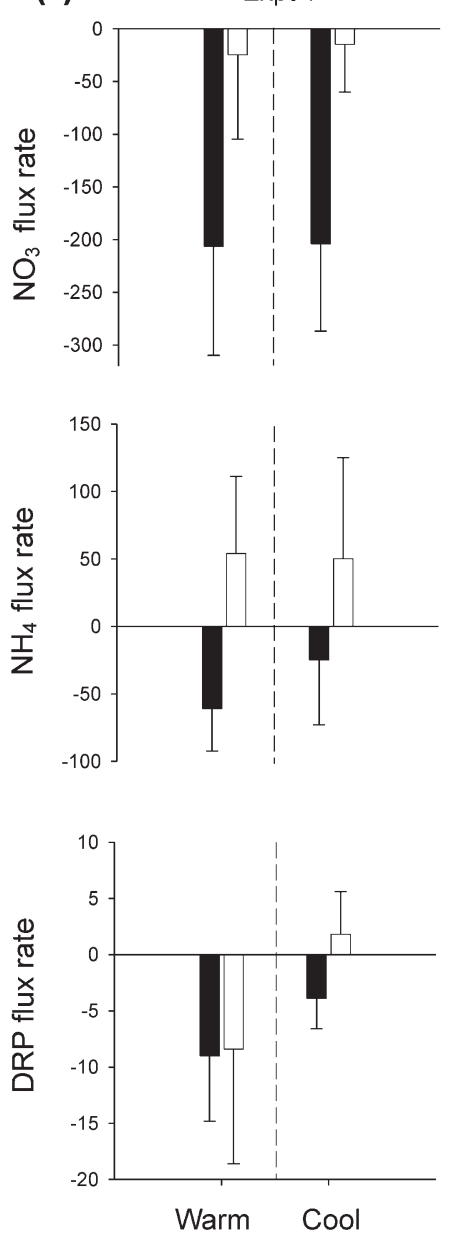
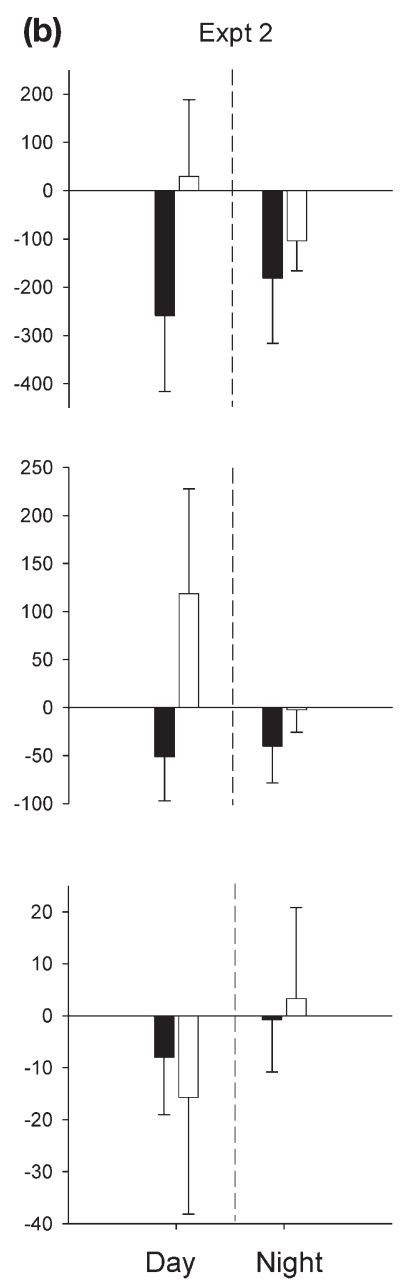

Fig. 2. Expts 1 and 2. Mean daytime nutrient flux rates in Zostera japonica habitats (black bars) and unvegetated sediment habitats (white bars), in (a) warm (May to August) and cool (January to April) seasons, and (b) in daylight and at night. Positive rates indicate efflux, negative rates influx; error bars $=95 \%$ CI. In (a) $\mathrm{n}=18$ in warm season, 10 in cool

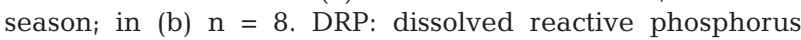

rates in $Z$. japonica habitats were twice as high as in the cool season (Fig. 2a). These differences were significant, but the main effect of season on $\mathrm{NO}_{3}$ flux rates was not significant (Table 2). Differences among locations in Yaquina Bay ('Blocks' in Table 2) were significant for each nutrient. The among-location variability in nutrient fluxes prevented the determination of net flux directions in each habitat and season.

$\mathrm{NO}_{3}$ influx rates in $Z$. japonica habitats increased with increasing above-ground seagrass biomass in both seasons (Table 3). The slope of the regression for the warm season was significantly steeper than for the cool season, i.e. $\mathrm{NO}_{3}$ influx per unit above-ground biomass was greater during the warm season (Student's $t$-test of slopes, $t=2.35, \mathrm{df}=25, \mathrm{p}<0.05$ ). Regressions of $\mathrm{NH}_{4}$ and DRP flux rates on above-ground biomass, and regressions of all nutrient flux rates on belowground biomass were not significant.

Porewater $\mathrm{NO}_{3}$ and $\mathrm{NH}_{4}$ concentrations were twice as high, and sediment chlorophyll a concentrations were $20 \%$ higher in unvegetated sediments than in Zostera japonica habitats (Table 4). These betweenhabitat differences were significant (ANOVA, p < 0.05). Smaller between-habitat differences in grain size, grain size heterogeneity and particulate nutrient concentrations were not significant (Table 4). There were significant between-season differences in several

Table 3. Zostera japonica and Z. marina. Regressions of nutrient flux rates $\left(\mu \mathrm{mol} \mathrm{m} \mathrm{m}^{-2} \mathrm{~h}^{-1}\right)$ on above-ground biomass (g ash-free dry wt $\mathrm{m}^{-2}$ ). Regressions had slopes significantly different from zero $(p<0.05)$

\begin{tabular}{|lcrrc|}
\hline $\begin{array}{l}\text { Species } \\
\text { Expt }\end{array}$ & Nutrient & Slope & Intercept & $\mathrm{R}^{2}$ \\
\hline $\begin{array}{l}\text { Z. japonica } \\
1 \text { (warm season) }\end{array}$ & $\mathrm{NO}_{3}$ & -21.3 & 590.8 & 0.33 \\
1 (cool season) & $\mathrm{NO}_{3}$ & -5.1 & -12.7 & 0.27 \\
3 & $\mathrm{NO}_{3}$ & -4.6 & 2.7 & 0.68 \\
$Z$ marina & & & & \\
3 & $\mathrm{NO}_{3}$ & -1.6 & -97.6 & 0.83 \\
3 & $\mathrm{DRP}$ & 0.07 & -11.4 & 0.76 \\
\hline
\end{tabular}


Table 4. Expt 1. Sediment properties in Zostera japonica and unvegetated sediment habitats in warm and cool seasons. Values are means \pm 1 SD. $\mathrm{n}=18$ in warm season, 10 in cool season except where shown in parentheses

\begin{tabular}{|c|c|c|c|c|}
\hline \multirow[t]{2}{*}{ Variable } & \multicolumn{2}{|c|}{ Z. japonica } & \multicolumn{2}{|c|}{ Unvegetated sediment } \\
\hline & Warm & Cool & Warm & Cool \\
\hline Mean grain size (mm) & $0.3 \pm 0.2$ & $0.2 \pm 0.1$ & $0.3 \pm 0.2$ & $0.2 \pm 0.1$ \\
\hline Grain size heterogeneity (mm) & $0.5 \pm 0.3$ & $0.4 \pm 0.2$ & $0.5 \pm 0.4$ & $0.4 \pm 0.2(5)$ \\
\hline POC (\% dry wt) & $1.2 \pm 0.9$ & $1.4 \pm 1.2$ & $1.3 \pm 1.0$ & $1.4 \pm 1.4(5)$ \\
\hline PN (\% dry wt) & $0.1 \pm 0.1$ & $0.3 \pm 0.1$ & $0.1 \pm 0.1$ & $0.2 \pm 0.1(5)$ \\
\hline PP (\% dry wt) & $0.002 \pm 0.001$ & $0.002 \pm 0.001$ & $0.002 \pm 0.0004$ & $0.002 \pm 0.001(5)$ \\
\hline Porewater $\mathrm{NO}_{3}(\mu \mathrm{M})$ & $0.8 \pm 1.0$ & $0.8 \pm 1.8$ & $1.2 \pm 1.4$ & $2.0 \pm 3.7$ \\
\hline Porewater $\mathrm{NH}_{4}(\mu \mathrm{M})$ & $66.1 \pm 51.7$ & $60.2 \pm 61.1$ & $97.6 \pm 70.0$ & $170.2 \pm 104.5$ \\
\hline Porewater DRP $(\mu \mathrm{M})$ & $3.29 \pm 6.86$ & $5.46 \pm 12.92$ & $4.26 \pm 9.18$ & $5.57 \pm 8.24$ \\
\hline Sediment chlorophyll a $\left(\mathrm{mg} \mathrm{m}^{-2}\right)$ & $56.4 \pm 16.4$ & $61.7 \pm 28.0$ & $81.4 \pm 29.2$ & $67.0 \pm 35.6$ \\
\hline
\end{tabular}

sediment variables: $\mathrm{PN}$ and porewater $\mathrm{NO}_{3}$ and DRP concentrations were higher in the cool season, and mean grain sizes were larger during the warm season (Table 4).

\section{Expt 2. Day-night differences in nutrient flux rates}

Zostera japonica habitats were net sinks for both $\mathrm{NO}_{3}$ and $\mathrm{NH}_{4}$ during the day and at night (Fig. 2b). Unvegetated sediments were net sinks for $\mathrm{NO}_{3}$ at night, and net sources of $\mathrm{NH}_{4}$ during the day (Fig. 2b). Nighttime $\mathrm{NH}_{4}$ fluxes and daytime $\mathrm{NO}_{3}$ fluxes in unvegetated sediments, and DRP fluxes in both habitats at both light levels were too variable to determine net directions.

There were significant differences in $\mathrm{NH}_{4}$ fluxes between habitats and between light levels (Table 5). The habitat $\times$ light interaction was also significant for $\mathrm{NH}_{4}$, because efflux from unvegetated sediments was rapid in daylight and decreased to near-zero at night, while $\mathrm{NH}_{4}$ influx to Zostera japonica habitats in daylight was $20 \%$ higher than at night (Fig. 2b). There was a significant between-habitat difference in $\mathrm{NO}_{3}$ flux, and the habitat $\times$ light interaction for $\mathrm{NO}_{3}$ was significant, but the main effect of light was not significant (Table 5). The $\mathrm{NO}_{3}$ interaction was also due to the large difference between habitats in daylight, and the smaller difference at night. Between-habitat and between light-level differences in DRP flux rates were not significant. Differences in flux rates among locations were significant for each nutrient.
On a diel basis, Zostera japonica habitats were net sinks for both $\mathrm{NO}_{3}$ and $\mathrm{NH}_{4}$, and unvegetated sediments were net sources of $\mathrm{NH}_{4}$ (Table 6). Diel rates of DRP flux in both habitats were too variable to determine net directions. Although unvegetated sediments were net $\mathrm{NO}_{3}$ sinks at night, this pattern was offset by high variability in daylight, and the diel $\mathrm{NO}_{3}$ fluxes were also too variable to determine net direction.

\section{Expt 3. Nutrient fluxes in Zostera japonica and Z. marina habitats}

At locations where daytime nutrient flux measurements were made in adjacent Zostera japonica and $Z$. marina habitats, both species were net sinks for $\mathrm{NO}_{3}$,

Table 5. Expt 2. Summaries of factorial ANOVAs comparing flux rates of $\mathrm{NO}_{3}$ $\mathrm{NH}_{4}$ and DRP in Zostera japonica and unvegetated sediment habitats at 2 light levels (daylight vs darkness). Experimental runs were from May to August 1999. Blocks $=$ locations in Yaquina Bay

\begin{tabular}{|lrrcrcrrr|}
\hline Source & df & \multicolumn{2}{c}{$\mathrm{NO}_{3}$} & \multicolumn{2}{c}{ DRP } & \multicolumn{2}{c|}{$\mathrm{NH}_{4}$} \\
& & \multicolumn{1}{c}{$\mathrm{MS}$} & $\mathrm{p}$ & $\mathrm{MS}$ & $\mathrm{p}$ & $\mathrm{MS}$ & $\mathrm{p}$ \\
\hline Habitat & 1 & 267909.8 & 0.002 & 86405.8 & $<0.001$ & 26.0 & 0.8 \\
Light level & 1 & 6356.4 & 0.6 & 24294.2 & 0.04 & 1367.9 & 0.09 \\
Interaction & 1 & 88574.8 & 0.06 & 34737.9 & 0.017 & 279.8 & 0.4 \\
Blocks & 3 & 303734.2 & $<0.001$ & 20832.7 & 0.019 & 1582.8 & 0.03 \\
Error & 25 & 23596.6 & & 5259.3 & & 437.5 & \\
\hline
\end{tabular}

Table 6. Expt 2. Diel fluxes of $\mathrm{NO}_{3}, \mathrm{NH}_{4}$ and DRP in Zostera japonica and unvegetated sediment habitats $\left(\mu \mathrm{mol} \mathrm{m} \mathrm{m}^{-2} \mathrm{~d}^{-1}\right)$. Values are means $\pm 95 \% \mathrm{CI}_{i} \mathrm{n}=8$. Positive signs indicate efflux, negative signs influx

\begin{tabular}{|lccc|}
\hline Habitat & $\mathrm{NO}_{3}$ & $\mathrm{NH}_{4}$ & $\mathrm{DRP}$ \\
\hline Z. japonica & $-1654.7 \pm 1327.0$ & $-338.9 \pm 274.6$ & $-38.2 \pm 69.2$ \\
Unvegetated sediment & $-143.9 \pm 894.2$ & $+530.3 \pm 429.0$ & $-62.0 \pm 125.6$ \\
\hline
\end{tabular}



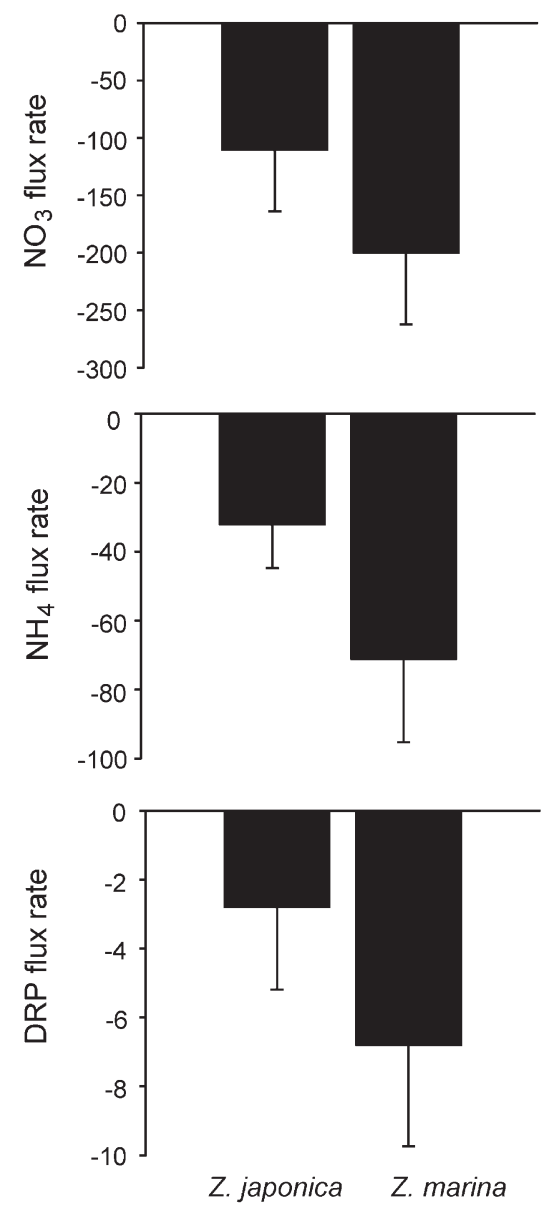

Fig. 3. Expt 3. Mean nutrient influx rates in Zostera japonica and $Z$. marina habitats. Error bars $=95 \% \mathrm{CI}_{i} \mathrm{n}=6$

$\mathrm{NH}_{4}$, and DRP (Fig. 3). Mean rates of $\mathrm{NO}_{3}, \mathrm{NH}_{4}$, and DRP influx to $Z$. marina habitats were about twice the mean rates of influx to $Z$. japonica habitats. Differences between seagrass species in $\mathrm{NH}_{4}$ and DRP influx rates were significant (ANOVA, p < 0.05), and the difference in $\mathrm{NO}_{3}$ influx rates was marginally significant $(\mathrm{p}=0.064)$.

$\mathrm{NO}_{3}$ influx rates increased with above-ground seagrass biomass in both Zostera japonica and Z. marina habitats (Table 3). The slope of the $\mathrm{NO}_{3}$ regression was steeper for $Z$. japonica, i.e. $\mathrm{NO}_{3}$ influx per unit biomass was higher for Z japonica habitats (Student's $t$-test of slopes, $t=3.42$, df $=8, \mathrm{p}<0.01$ ). DRP influx decreased with increasing above-ground biomass in $Z$. marina habitats (Table 3). DRP flux rates were not related to above-ground $Z$. japonica biomass, and $\mathrm{NH}_{4}$ fluxes were not related to above-ground biomass for either seagrass. Regressions using below-ground biomass were not significant. Differences between seagrass species in areal nutrient flux rates may have been due to differences in above-ground biomass at the study locations. Mean above-ground biomass of Z. marina was $65.9 \mathrm{~g} \mathrm{AFDW} \mathrm{m}^{-2}$, compared with $24.6 \mathrm{~g}$ AFDW $\mathrm{m}^{-2}$ for $Z$. japonica.

Mean sediment grain sizes, sediment heterogeneity, and porewater $\mathrm{NH}_{4}$ concentrations were significantly higher in Z. japonica habitats than in Zostera marina habitats (Table 7, ANOVA, p < 0.03). Differences between seagrass species in particulate nutrient and porewater $\mathrm{NO}_{3}$ and DRP concentrations were not significant.

\section{Nutrient flux correlations and Zostera japonica biomass patterns}

Associations between nutrient fluxes in Zostera japonica habitats and physical and chemical variables were identified by linear correlation, using data from all 3 experiments. Only coefficients for significant $(\mathrm{p}<0.05)$ correlations are reported. $\mathrm{NO}_{3}$ flux was positively correlated with temperature $(\mathrm{r}=0.71)$ and ambient $\mathrm{NO}_{3}$ concentration $(\mathrm{r}=0.66)$. $\mathrm{NH}_{4}$ flux was positively correlated with irradiance $(\mathrm{r}=0.68)$ and ambient $\mathrm{NH}_{4}$ concentration $(\mathrm{r}=0.86)$. DRP flux was positively correlated with temperature $(\mathrm{r}=0.64)$. No significant correlations between nutrient fluxes and sediment grain size structure, porewater or particulate nutrients, or sediment chlorophyll a were detected.

Intertidal Zostera japonica has been reported to be an annual in Washington and British Columbia (Harrison 1979, Thom 1990), but plants were present throughout the year in Yaquina Bay (Fig. 4). Mean annual above-ground $Z$. japonica biomass at the 8 locations monitored ranged from 15 to $42 \mathrm{~g}$ AFDW $\mathrm{m}^{-2}$. Mean annual below-ground biomass ranged from 14 to $60 \mathrm{~g} \mathrm{AFDW} \mathrm{m}^{-2}$. A seasonal cycle is evident in above-ground biomass, with maximum levels in late summer and early fall, and minimum levels in early spring (Fig. 4). Seasonal patterns were not evident in below-ground or total biomass (data not shown).

Table 7. Expt 3. Sediment properties in Zostera japonica and Z. marina habitats. Values are means $\pm 1 \mathrm{SD}, \mathrm{n}=9$ for all variables

\begin{tabular}{|lcc|}
\hline \multirow{2}{*}{ Variable } & \multicolumn{2}{c|}{ Species } \\
& $Z$. japonica & Z. marina \\
\hline Mean grain size $(\mathrm{mm})$ & $0.71 \pm 0.10$ & $0.55 \pm 0.12$ \\
Grain size heterogeneity $(\mathrm{mm})$ & $1.17 \pm 0.12$ & $1.03 \pm 0.06$ \\
$\mathrm{POC}(\%$ dry wt) & $1.43 \pm 0.61$ & $1.71 \pm 0.81$ \\
$\mathrm{PN}(\%$ dry wt) & $0.10 \pm 0.04$ & $0.12 \pm 0.05$ \\
$\mathrm{PP}(\%$ dry w) & $0.002 \pm 0.0002$ & $0.002 \pm 0.0004$ \\
Porewater $\mathrm{NO}_{3}(\mu \mathrm{M})$ & $0.88 \pm 0.75$ & $0.75 \pm 0.82$ \\
Porewater $\mathrm{NH}_{4}(\mu \mathrm{M})$ & $66.13 \pm 21.51$ & $33.82 \pm 14.57$ \\
Porewater $\mathrm{DRP}(\mu \mathrm{M})$ & $0.22 \pm 0.11$ & $0.28 \pm 0.27$ \\
\hline
\end{tabular}




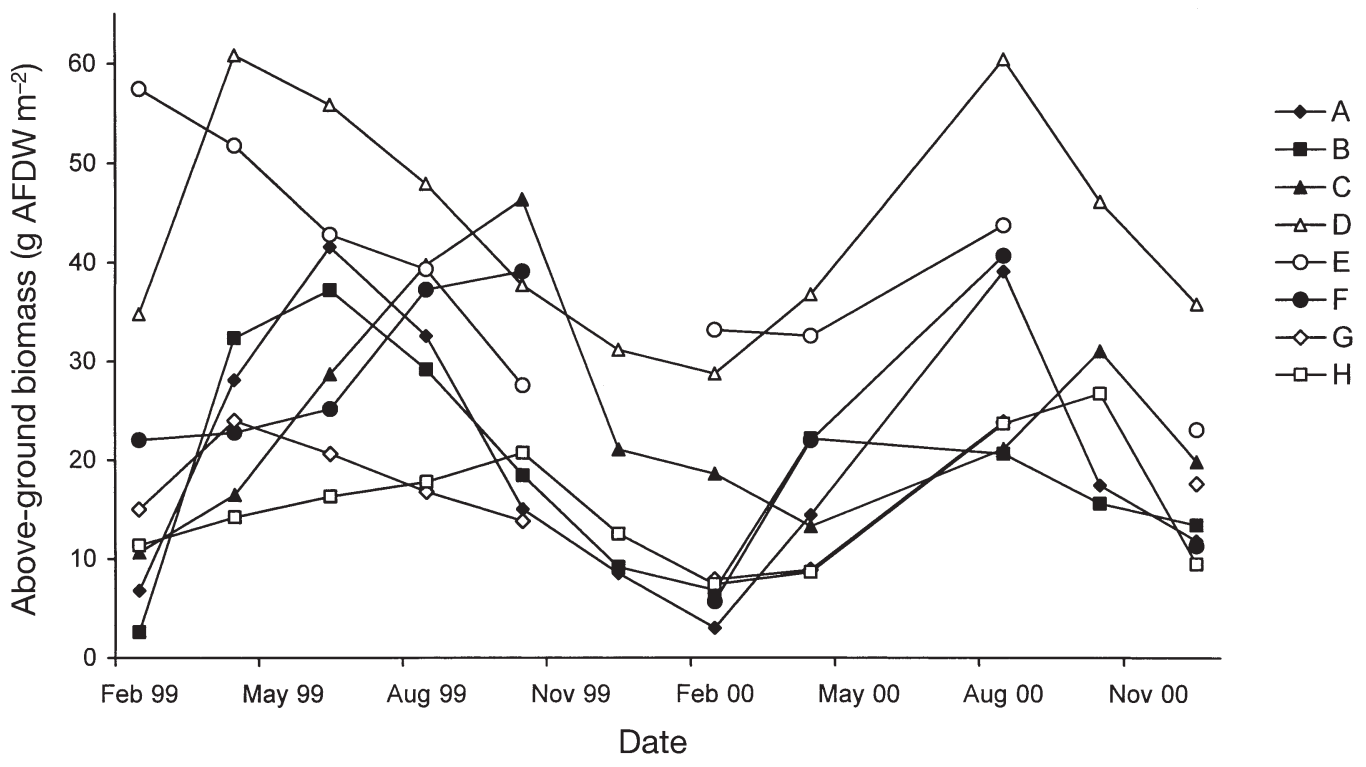

Fig. 4. Zostera japonica. Above-ground biomass in Yaquina Bay. Letters in key: locations on Fig. 1. Data points are means of 10 samples at Location F, 11 samples at Locations E and G, and 12 samples at the remaining locations. AFDW: ash-free dry wt

\section{DISCUSSION}

Dissolved nutrient fluxes between the water column, and benthos represent the balance between processes that remove nutrients from the water column such as biotic assimilation, and processes that release nutrients, such as organic matter remineralization and excretion (Hemminga et al. 1991, Cowan et al. 1996, Risgaard-Petersen et al. 1998). Zostera japonica can shift this balance in the upper intertidal sediments it colonizes. Unvegetated sediments in Yaquina Bay were a source of $\mathrm{NH}_{4}$ to the water column in both the warm and cool season, with little net flux of $\mathrm{NO}_{3}$ or DRP. When $Z$. japonica occupied the same zone, the benthos was a net sink for $\mathrm{NO}_{3}$ and DRP in both seasons, and a sink for $\mathrm{NH}_{4}$ in the warm season.

In NE Pacific estuaries that have been invaded by Zostera japonica, alterations in nutrient fluxes may increase over time as biomass accumulates in new and expanding patches. Established Z. japonica patches in Yaquina Bay did not appear to increase in biomass during my 22 mo study (Fig. 4), but new patches appeared in spring in previously unvegetated sediment (own pers. obs.). Continued monitoring is required to assess long-term changes in $Z$. japonica biomass. Seagrass patches that are not expanding may still be long-term sinks for dissolved nutrients. Nutrient leaching from living and scenesent seagrass tissues is generally orders of magnitude slower than uptake by live tissue (Buchsbaum et al. 1991, Enríquez et al. 1993), and nutrient losses in the form of detritus generally exceed dissolved nutrient losses in temperate seagrass beds (Bach et al. 1986, Pedersen \& Borum 1993).
At the time of the study (1999 and 2000), Zostera japonica occupied between 1 and $5 \%$ of the intertidal area of the marine and mesohaline zones of Yaquina Bay, based on image-analysis of digitized airphotos (P. Clinton pers. comm.). More accurate measurements of $Z$. japonica cover are not yet available, so estimates of the estuary-wide effects of $Z$. japonica are rough. Conservative estimates of estuary-wide effects were made by assuming a percent cover value of $1 \%\left(\sim 24 \times 10^{4} \mathrm{~m}^{2}\right.$ of the $24 \mathrm{~km}^{2}$ intertidal area) and using nutrient flux rates averaged across the study locations. Z. japonica habitats are estimated to remove 50 to $60 \mathrm{~mol} \mathrm{DIN} \mathrm{h}^{-1}$ and 0.2 to $2.2 \mathrm{~mol} \mathrm{DRP} \mathrm{h}^{-1}$ from the Yaquina Bay water column during the day (Table 8). Estimated rates of estuary-wide diel influx to Z. japonica habitats, made only for the warm season when both day and night fluxes were measured, are $1595 \mathrm{~mol} \mathrm{DIN} \mathrm{d}^{-1}$ (1324 mol $\mathrm{NO}_{3} \mathrm{~d}^{-1}$ and $271 \mathrm{~mol} \mathrm{NH}_{4} \mathrm{~d}^{-1}$ ), and $31 \mathrm{~mol} \mathrm{DRP} \mathrm{d} \mathrm{d}^{-1}$. If $Z$. japonica cover in Yaquina Bay increases to the point that the marine-mesohaline area within the $Z$. japonica tidal range $\left(\sim 8 \times 10^{6} \mathrm{~m}^{2}\right)$ is entirely occupied, effects on

Table 8. Estimated estuary-wide nutrient flux rates in Zostera japonica habitat $\left(\mathrm{mol} \mathrm{h} \mathrm{h}^{-1}\right)$. Estimates are products of measured flux rates and conservative estimate of intertidal area of Yaquina Bay covered by $Z$. japonica $\left(24 \times 10^{4} \mathrm{~m}^{2}\right)$

\begin{tabular}{|lccc|}
\hline Period/season & \multicolumn{3}{c|}{$\begin{array}{c}\text { Hourly flux rate } \\
\mathrm{NH}_{4}\end{array}$} \\
\hline Daylight/cool & -48.9 & -6.0 & -0.9 \\
Daylight/warm & -49.6 & -14.6 & -2.2 \\
Night/warm & -43.6 & -9.7 & -0.2 \\
\hline
\end{tabular}


nutrient fluxes could be quite severe. In this worst-case scenario, estimated diel influx rates due to $Z$. japonica are 44090 mol $\mathrm{NO}_{3} \mathrm{~d}^{-1}, 9024 \mathrm{~mol} \mathrm{NH}_{4} \mathrm{~d}^{-1}$, and 1032 mol DRP d ${ }^{-1}$.

The conversion of intertidal sediments from net sources of inorganic nutrients to net sinks following an invasion of Zostera japonica may affect pelagic productivity. DIN and DRP efflux has been shown to supply most of the nitrogen and phosphorus required for phytoplankton growth in other shallow estuaries (Rizzo 1990, Reay et al. 1995, Cowan et al. 1996). Estuarine phytoplankton may become nutrient-limited following the establishment of nonindigenous seagrasses due to reduced benthic efflux. Even in the absence of seagrasses, phytoplankton in seasonally riverdominated estuaries such as Yaquina Bay may be limited by low nutrient input during low-flow seasons (Schemel et al. 1984, Mortazavi et al. 2000). Rates of $\mathrm{NH}_{4}$ and DRP influx to $Z$. japonica habitats in Yaquina Bay were highest during the summer low-flow season, indicating that reductions in benthic nutrient supplies to the water column coincided with reductions in river supplies.

Increased $\mathrm{NH}_{4}$ influx, reduced $\mathrm{NH}_{4}$ efflux, and shifts from $\mathrm{NH}_{4}$ efflux to influx have been observed during light periods in seagrass habitats and in sediments with abundant benthic microalgae (Rizzo et al. 1992, Thornton et al. 1999, Hansen et al. 2000). These changes were attributed to light-dependent $\mathrm{NH}_{4}$ assimilation. $\mathrm{NH}_{4}$ influx to $Z$. japonica habitats was positively correlated with irradiance, and was significantly higher during the day than at night, consistent with previous studies. In contrast, $\mathrm{NH}_{4}$ efflux from unvegetated sediments increased during the day, rather than decreasing. This result was unexpected, because benthic microalgae were abundant in unvegetated sediments, as indicated by high sediment chlorophyll a concentrations (Table 4).

Unlike $\mathrm{NH}_{4}$ flux rates, $\mathrm{NO}_{3}$ flux rates in Zostera japonica habitats were not strongly affected by light. These results were also unexpected, as several benthic chamber studies of subtidal Zostera spp. habitats have reported higher rates of $\mathrm{NO}_{3}$ influx in light than in darkness (Risgaard-Petersen et al. 1998, Asmus et al. 2000, Hansen et al. 2000). Rizzo et al. (1992) attributed a lack of light-dependent $\mathrm{NO}_{3}$ influx in estuarine sediments to high water-column $\mathrm{NH}_{4}$ concentrations and repression of $\mathrm{NO}_{3}$ uptake by $\mathrm{NH}_{4}$. In the present study, water column $\mathrm{NO}_{3}$ concentrations were 3 to $17 \times$ higher than $\mathrm{NH}_{4}$ concentrations, and $\mathrm{NO}_{3}$ influx rates to $Z$. japonica habitats were $\sim 5 \times$ higher than $\mathrm{NH}_{4}$ influx rates, which suggests that there was little $\mathrm{NO}_{3}$ repression. Rapid $\mathrm{NO}_{3}$ influx at night suggests that the autotrophs in $Z$. japonica habitats maintain high levels of reducing power generated during the day. Welsh et al. (2000) suggested that dark nutrient uptake in intertidal seagrasses represents an adaptation to decoupled light and nutrient availability in estuaries with semidiurnal tidal regimes, such as Yaquina Bay. Water column nutrients are unavailable during daylight low tides in these estuaries, and intertidal seagrasses must store photosynthetic reducing power to assimilate nutrients during the following high tide, when light may not be available.

The rapid growth of Zostera japonica patches in NE Pacific estuaries (Harrison \& Bigley 1982) raises the possibility that this species can outcompete and replace the native $Z$. marina, further altering nutrient source-sink patterns in the intertidal zone. Results from experimental and observational studies at a site where $Z$. marina and $Z$. japonica overlap suggested that $Z$. marina is competitively dominant, although unequivocal evidence is lacking (Nomme \& Harrison 1991a,b). During the warm season in Yaquina Bay, intertidal Z. marina habitat was a larger DIN sink than $Z$. japonica habitat on an area-specific basis; DIN influx in $Z$. marina habitat $\left(270 \mu \mathrm{mol} \mathrm{m} \mathrm{m}^{-2} \mathrm{~h}^{-1}\right)$ was nearly twice that in the $Z$. japonica habitat $(144 \mu \mathrm{mol}$ $\mathrm{m}^{-2} \mathrm{~h}^{-1}$ ). This difference was probably related to differences in biomass, as the above-ground biomass of intertidal $Z$. marina was almost $3 \times$ higher than that of $Z$. japonica. $Z$. japonica had a higher mean $\mathrm{NO}_{3}$ influx rate per unit above-ground biomass than $Z$. marina (Table 3), and if biomass levels of $Z$. japonica increase in the future, they may be accompanied by increased $\mathrm{NO}_{3}$ influx.

Porewater DIN concentrations in the root zone of Zostera japonica habitats were low compared with the same depth in unvegetated sediments (Table 4). Similar patterns have been observed in some seagrass systems (Short 1983, Caffrey \& Kemp 1990), while other studies have reported higher porewater $\mathrm{NH}_{4}$ concentrations in seagrass habitats (Kenworthy et al. 1982). Reduced porewater DIN in seagrass habitats has been attributed to uptake by roots and rhizomes at rates higher than regeneration rates (Short 1983, Short et al. 1993). This hypothesis is supported by the results of field studies in which porewater DIN increased following seagrass removal, decreased following seagrass colonization of unvegetated sediment, and decreased further as seagrass biomass increased (Short 1983, Short et al. 1993). The results of the present study add some circumstantial evidence to the hypothesis. The mean porewater $\mathrm{NH}_{4}$ concentration in Z. japonica habitats was twice that in $Z$. marina habitats (Table 7), a difference that may reflect higher rates of sediment nitrogen uptake in $Z$. marina habitats with greater biomass.

The establishment of Zostera japonica clearly alters patterns of the water column-benthos nutrient flux in 
the Yaquina Bay intertidal zone. These changes appear to be the direct effects of $Z$. japonica leaves and shoots, and not indirect effects of altered sediment properties. This interpretation is supported by the significant linear regressions relating $\mathrm{NO}_{3}$ influx to above-ground $Z$. japonica biomass (Table 3 ) and the lack of significant correlations between nutrient flux in $Z$. japonica habitats and sediment properties.

Acknowledgements. Many thanks to W. Dengal, P. Eldridge, M. Gobershock, C. Mohlmann, G. Sullivan, and J. Thompson for assistance in the field, and to the staff of Dynamac Corporation for assistance with sediment analyses. D. Specht kindly provided sediment temperature data, and P. Clinton provided areal coverage data for Yaquina Bay. Reviews by D. Bulthuis, J. Kaldy, R. Thom and 2 anonymous reviewers improved the manuscript. The research reported in this manuscript has been funded wholly by the US Environmental Protection Agency. The manuscript has been subjected to the Agency's peer and administrative review and has been approved for publication as an EPA document. Mention of trade names or commercial products does not constitute endorsement or recommendation for use.

\section{LITERATURE CITED}

Asmus RM, Sprung M, Asmus H (2000) Nutrient fluxes in intertidal communities of a South European lagoon (Ria Formosa) - similarities and differences with a northern Wadden Sea bay (Sylt-Rømø Bay). Hydrobiologia 436: 217-235

Bach SD, Thayer GW, LaCroix, MW (1986) Export of detritus from eelgrass (Zostera marina) beds near Beaufort, North Carolina, USA. Mar Ecol Prog Ser 28:265-278

Buchanan JB (1984) Sediment analysis. In: Holme NA, McIntyre $\mathrm{AD}$ (eds) Methods for the study of marine benthos. IBP Handbook 16, 2nd edn. Blackwell Scientific Publishers, Boston, p 41-65

Buchsbaum R, Valiela I, Swain T, Dzierzeski M, Allen S (1991) Available and refractory nitrogen in detritus of coastal vascular plants and macroalgae. Mar Ecol Prog Ser 72: 131-143

Caffrey JM, Kemp WM (1990) Nitrogen cycling in sediments with estuarine populations of Potamogeton perfoliatus and Zostera marina. Mar Ecol Prog Ser 66:147-160

Cohen AN, Carlton, JT (1998) Accelerating invasion rate in a highly invaded estuary. Science 279:555-557

Cowan JLW, Pennock JR, Boynton WR (1996) Seasonal and interannual patterns of sediment-water nutrient and oxygen fluxes in Mobile Bay, Alabama (USA): regulating factors and ecological significance. Mar Ecol Prog Ser 141: $229-245$

Eno NC (1996) Non-native marine species in British waters: effects and controls. Aquat Conserv Mar Freshw Ecosys $6: 215-228$

Enríquez S, Duarte CM, Sand-Jensen K (1993) Patterns in decomposition rates among photosynthetic organisms: the importance of detritus C:N:P content. Oecologia 94: $457-471$

Forja JM, Gomez-Parra A (1998) Measuring nutrient fluxes across the sediment-water interface using benthic chambers. Mar Ecol Prog Ser 164:95-105

Gordon DR (1998) Effects of invasive, non-indigenous plant species on ecosystem processes: lessons from Florida. Ecol Appl 8:975-989

Hansen J, Pedersen AU, Berntsen J, Ronbog IS, Hansen LS, Lomstein BA (2000) Photosynthesis, respiration and nitrogen uptake by different compartments of a Zostera marina community. Aquat Bot 66:281-295

Harrison PG (1979) Reproductive strategies in intertidal populations of two co-occurring seagrasses (Zostera spp.). Can J Bot 57:2635-2638

Harrison PG, Bigley RE (1982) The recent introduction of the seagrass Zostera japonica Aschers. and Graebn. to the Pacific coast of North America. Can J Fish Aquat Sci 39: 1642-1648

Hemminga MA, Harrison PG, van Lent F (1991) The balance of nutrient losses and gains in seagrass meadows. Mar Ecol Prog Ser 71:85-96

Hemminga MA, Koutstaal BP, van Soelen J, Merks AJA (1994) The nitrogen supply to intertidal eelgrass (Zostera marina). Mar Biol 118:223-227

Kenworthy WJ, Zieman JC, Thayer GW (1982) Evidence for the influence of seagrasses on the benthic nitrogen cycle in a coastal plain estuary near Beaufort, North Carolina (USA). Oecologia 54:152-158

Meyerson LA, Chambers RM, Vogt KA (1999) The effects of Phragmites removal on nutrient pools in a freshwater tidal marsh ecosystem. Biol Invasions 1:129-136

Mortazavi B, Iverson RL, Landing WM, Lewis FG, Huang W (2000) Control of phytoplankton production and biomass in a river-dominated estuary: Apalachicola Bay, Florida, USA. Mar Ecol Prog Ser 198:19-31

Nomme KM, Harrison PG (1991a) A multivariate comparison of the seagrasses Zostera marina and Zostera japonica in monospecific versus mixed populations. Can J Bot 69: $1984-1990$

Nomme KM, Harrison PG (1991b) Evidence for interaction between the seagrasses Zostera marina and Zostera japonica on the Pacific coast of Canada. Can J Bot 69: 2004-2010

Pedersen MF, Borum J (1993) An annual nitrogen budget for a seagrass Zostera marina population. Mar Ecol Prog Ser 101:169-177

Pérez-Lloréns JL, de Visscher P, Nienhuis PH, Niell FX (1993) Light-dependent uptake, translocation and foliar release of phosphorus by the intertidal seagrass Zostera noltii Hornem. J Exp Mar Biol Ecol 166:165-174

Posey MH (1988) Community changes associated with the spread of an introduced seagrass, Zostera japonica. Ecology 69:974-983

Posey MH, Wigand C, Stevenson JC (1993) Effects of an introduced aquatic plant, Hydrilla verticillata, on benthic communities in the upper Chesapeake Bay. Estuar Coast Shelf Sci 37:539-555

Reay WG, Gallagher DL, Simmons GM (1995) Sedimentwater column oxygen and nutrient fluxes in nearshore environments of the lower Delmarva Peninsula, USA. Mar Ecol Prog Ser 118:215-227

Risgaard-Petersen N, Dalsgaard T, Rysgaard S, Christensen PB, Borum J, McGlathery K, Nielsen LP (1998) Nitrogen balance of a temperate eelgrass Zostera marina bed. Mar Ecol Prog Ser 174:281-291

Rizzo WM (1990) Nutrient exchanges between the water column and a subtidal benthic microalgal community. Estuaries 13:219

Rizzo WM, Lackey GJ, Christian RR (1992) Significance of euphotic, subtidal sediments to oxygen and nutrient cycling in a temperate estuary. Mar Ecol Prog Ser 86: $51-61$ 
Rooth SE, Stevenson JC (2000) Sediment deposition patterns in Phragmites australis communities: implications for coastal areas threatened by rising sea-level. Wetlands Ecol Manage 8:173-183

Ruiz GM, Fofonoff P, Hines AH, Grosholz ED (1999) Nonindigenous species as stressors in estuarine and marine communities: assessing invasion impacts and interactions. Limnol Oceanogr 44:950-972

Schemel LE, Harmon DD, Hager SW, Peterson DH (1984) Response of northern San Francisco Bay to riverine inputs of dissolved inorganic carbon, silicon, nitrogen and phosphorus. In: Kennnedy VS (ed) The estuary as a filter. Academic Press, New York, p 221-240

Short FT (1983) The response of interstitial ammonium in eelgrass (Zostera marina L.) beds to environmental perturbations. J Exp Mar Biol Ecol 68:195-208

Short FT, Montgomery J, Zimmermann CF, Short CA (1993) Production and nutrient dynamics of a Syringodium filiforme Kütz: seagrass bed in Indian River Lagoon, Florida. Estuaries 16:323-334

Editorial responsibility: Kenneth Heck (Contributing Editor), Dauphin Island, Alabama, USA
Templer P, Findlay S, Wigand C (1998) Sediment chemistry associated with native and non-native emergent macrophytes of a Hudson River marsh ecosystem. Wetlands 18: $70-78$

Thom RM (1990) Spatial and temporal patterns in plant standing stock and primary production in a temperate seagrass system. Bot Mar 33:497-510

Thornton DCO, Underwood GJC, Nedwell DB (1999) Effect of illumination and emersion period on the exchange of ammonium across the estuarine sediment-water interface. Mar Ecol Prog Ser 184:11-20

Turner CE, Center TD, Burrows DW, Buckingham GR (1998) Ecology and management of Melaleuca quinquenervia, an invader of wetlands in Florida, USA. Wetlands Ecol Manage 5:165-178

Welsh DT, Bartoli M, Nizzoli D, Castadelli G, Riou SA, Viaroli P (2000) Denitrification, nitrogen fixation, community primary productivity and inorganic- $\mathrm{N}$ and oxygen fluxes in an intertidal Zostera noltii meadow. Mar Ecol Prog Ser 208:65-77

Submitted: April 3, 2002; Accepted: December 5, 2002 Proofs received from author(s): May 12, 2003 